\title{
The influence of Organizational Support and Management of Employee Performance Marketing in Mediation by Competence
}

\author{
Magus Sitindaon ${ }^{1}$, Hery Winoto $\mathrm{Tj}^{1^{*}}$, Melitina Tecoalu ${ }^{1}$ \\ ${ }^{1}$ Faculty of Economics and Business, Krida Wacana Christian University, Jakarta 11470, Indonesia \\ ${ }^{*}$ Corresponding author
}

Email: hery.winoto@ukrida.ac.id

\begin{abstract}
.
These studies identify and analyze the implications of organizational support, management support, and employee competence on employee performance marketing. The study population was all employees of the marketing BPR Nusantara Bona Pasogit Group Region of West Java and Banten, which amounted to 115 people. Probability sampling technique is made to sampling, a total of 115 respondents who are employees of the marketing BPR Nusantara Bona Pasogit Group Region of West Java and Banten became the sample in the study. This study uses the approach of analysis of structural equation (SEM) using smartPLS. The results of the analysis indicates organizational support has an influence on employee performance marketing at BPR Nusantara Bona Pasogit (NBP) Group Region of West Java and Banten, as well as management support affect the performance of employees marketing at BPR Nusantara Bona Pasogit (NBP) Group Region of West Java and Banten. In addition found also that the support of the organization affect the competence of employees of marketing at BPR Nusantara Bona Pasogit (NBP) Group Region of West Java and Banten.
\end{abstract} Keywords : Organizational Support, Management Support, Competency and Performance
of Employees.

\section{INTRODUCTION}

The employee was instrumental in the achievement of the goals of the organization and the success of the organization. Skills, knowledge and competence of employees is very necessary for the planning and implementation of the strategy of organizations. This is reinforced by Joarder et al (2015) who stressed the importance of improving the performance of employees because it will produce a competitive advantage. Employee performance plays an important role for the organization in the delivery of competitive advantage, one of them is a company engaged in the sector of fund raising and lending such as the Bank Perkreditan Rakyat (BPR). The performance of the BPR is growing in Indonesia, it is not regardless of the market share of RB large enough that the SMES whose number increased from year to year.Besides, the existence of RB is close to the center of the activities of SMES so as to facilitate BPR to reach out to SMES and serve their financial needs. The development of the BPR rapid has been successfully serving the community both in terms of ease of access to the community, the steps are easier, and the priority of a personal approach as well as flexibility in the model of loan. Given the majority of businesses in Indonesia are SMES, the existence of rural banks to channel credit to the middle to the bottom which is generally oriented as SMES become very important. As businesses informally, the problem of capital become an obstacle to the development of its business, and capital in the form of credit from banking institutions such as rural banks can greatly help the development of small and medium-sized businesses. Company involved in the industry of Bank Perkreditan Rakyat (BPR), one of which is PT. Nusantara Bona Pasogit (NBP). The performance of the employees of the marketing BPR Nusantara Bona Pasogit (NBP) Group Region of West Java and Banten is currently not optimal, as seen from the table below that shows the target and achievement of the company in the last three years. 
Table 1. Performance indicators Employees Marketing BPR NBP Group Region West Java \& Banten

\begin{tabular}{|c|c|c|c|}
\hline Year & $\begin{array}{c}\text { The Target } \\
\text { Distribution } \\
\text { Of Credit } \\
\text { (in } \\
\text { thousands } \\
\text { of dollars) }\end{array}$ & $\begin{array}{c}\text { The } \\
\text { Realization } \\
\text { Of Credit } \\
\text { (in } \\
\text { thousands } \\
\text { of dollars) }\end{array}$ & Achievement \\
\hline 2017 & $415,012,498$ & $255,481,241$ & $62 \%$ \\
\hline 2018 & $438,751,352$ & $295,056,758$ & $67 \%$ \\
\hline 2019 & $409,029,512$ & $297,240,519$ & $73 \%$ \\
\hline
\end{tabular}

The performance of the marketing employee is not optimal because for the last three years (2017-2019) is still under $100 \%$ or has not reached the set target.Some empirical research on the influence of organizational support and management support on the performance of employees has been done by some previous research, among other research conducted by Moghli (2015). The results of these studies find support organizations positive effect on employee performance.Mohamed and Ali (2015) in his research showed if the support organization can improve the performance of the employee's job. Similarly, the relationship between the appreciation of the organization and support the organization shows no results.Fristin et al (2019) shows Perceived organizational support has a significant relationship and positively on job satisfaction, perceived organizational support has a positive influence and significant to employee engagement, perceived organizational support has positive relationship but no significant impact on the performance of workers. Zaim et al (2015) explained that there is a positive relationship between competence and human performance. These results show further evidence about the influence of competencies on organizational performance. Martini et al (2018) show there is a positive relationship between the competence with the performance. Manani and Ngui (2019) found that the competence of employees has a significant influence on employee performance.Bida and Majid (2017) examine the role of management support as a mediating variable that connects between the practices of human resources on the performance of employees. The results found that the practice of HR such as compensation, performance appraisal will be effective in improving employee performance if mediated by management support. Furthermore, Ismail et al (2019) found that management support to strengthen the effectiveness of their human resources practices to performance. Meanwhile, Pham et al (2016) gets the results of the management support has a direct influence positively to organizational commitment and employee performance.

Based on some previous research, it is known that it is still very rare researchers who examine the influence of organizational support and management support on the performance of employees with the competence of employees as a variable internverning. In addition, there are inconsistencies the results of the research where some researchers find support organizations have an influence on employee performance and on the other hand also found that the support organization has no influence on the performance of employees. On the basis of the persistence of the gap research above and not achieving the target set by the company through ten indicators, and declining performance of the BPR NBP Group Region of West Java and Banten, which is visible from the decrease in loans, deposits and profit before tax, then the researchers intend to test the effect of organizational support and management support on employee performance through the competence of employees in the BPR NBP Region of West Java and Banten. The formulation of the problem which will be examined more is :

1. Does the support organization have an influence on employee performance of marketing?

2. If management support has influence on employees performance marketing?

3. Does the support organization have an influence on the competence of the employees?

4. If management support has an influence on the competence of the employees? 
5. Whether the competence of the employees has an influence on employee performance of marketing?

6. Does the support organization have an influence on employee performance through employee competence?

7. If management support has influence to employee performance through employee competence?

Based on the formulation of the above then formed the framework of concepts and hypothesis as follows :

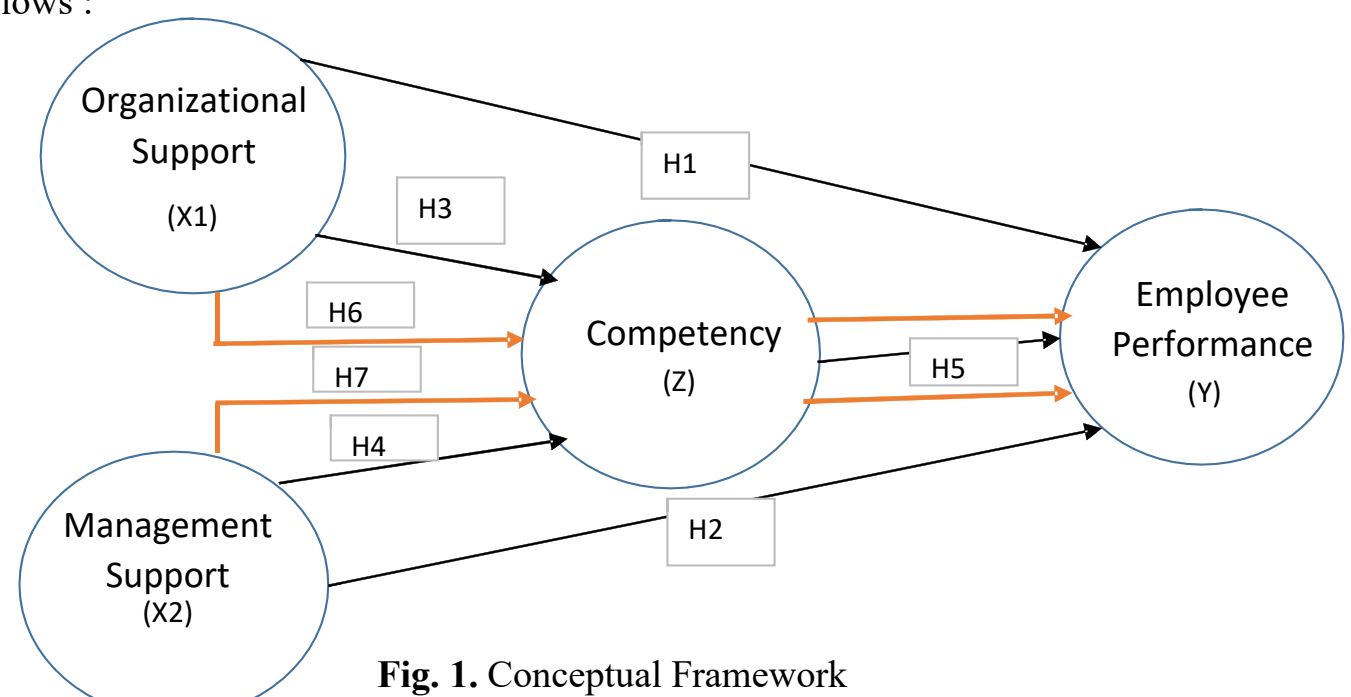

H1 : Support influential organization positive impact on employee performance marketing.

$\mathrm{H} 2$ : Support management effect on the performance of employees marketing.

H3 : Support influential organization of the competence.

H4 : Support management effect of the competence.

H5 : The competence of the influential positive impact on employee performance marketing.

H6 : Support influential organization on the performance of employees through competency.

H7: Support management effect on the performance of employees through competency.

\section{RESEARCH METHOD}

In this study the number of samples set is as much 115 respondents who are employees of the marketing BPR Nusantara Bona Pasogit Group Region of West Java and Banten. The sample obtained using the technique of probability sampling. Data collection techniques in this research is through primary data by using questionnaire instruments that are directly distributed to all the respondents of the study. Data analysis techniques in this research using Structural Equation Modelling (SEM) through Smart PLS.

\section{RESULTS AND DISCUSSION}

According to the results of the study, the characteristics of the respondents obtained the majority of the respondents were Male sex (76,5\%) and the majority are aged 31 to 40 years (to 46.1\%). Educational background of respondents the majority were high SCHOOL $(49,6 \%)$ and have prolonged periods of work for three to six years $(40,9 \%)$. The following is the test results of the descriptive statistics.

Table 2. Test Results Descriptive Statistics

\begin{tabular}{lc|c|c|c|r} 
& & $\begin{array}{c}\text { Minimu } \\
\mathrm{m}\end{array}$ & $\begin{array}{c}\text { Maximu } \\
\mathrm{m}\end{array}$ & Mean & $\begin{array}{c}\text { Std. } \\
\text { Deviation }\end{array}$ \\
\hline DO & 115 & 1,00 & 5,00 & 4,1687 &, 54682 \\
\hline DM & 115 & 1,63 & 5,00 & 4,1130 &, 53081 \\
\hline
\end{tabular}




\begin{tabular}{l|l|l|l|l|l}
\hline KOM & 115 & 2,00 & 5,00 & 4,1197 &, 42076 \\
\hline KIN & 115 & 2,00 & 5,00 & 4,1365 &, 45966 \\
\hline $\begin{array}{l}\text { Valid N } \\
\text { (listwise) }\end{array}$ & 115 & & & & \\
\hline Source ? Result Of Data Processing The Researcher (2020)
\end{tabular}

Source : Result Of Data Processing The Researcher (2020)

The above test can show variable support organization has a minimum value of 1.00 and a maximum of 5.00 with the acquisition of a mean value of 4,1678 and standard deviation of 0,54682 . Further, the variable management support shows a minimum value which is equal to 1.63 and the maximum of 5,00 with the acquisition of the average value (mean) of 4,1130 and standard deviation of 0,53081 . Then, the variable competence is worth a minimum of 2.00, and a maximum of 5,00 with the acquisition of a mean value of 4,1197 and standard deviation of 0,42076 . The last variable of employee performance have a minimum value of 2.00 , and a maximum of 5,00 with the acquisition of a mean of 4,1365 and standard deviation value 0,45966 .

The results of testing the outer model is done to determine the relationship between the signal and the difference of the latent. Therefore, the analysis of external mode describes how each signal in accordance with the difference current. This test is shown by testing the convergent and discriminant validity. According to Ghozali \& Latan (2015: 123), an indicator is considered to have clear conditions if it has elevation value above 0,70 . Thus, factor recording of 0.50 up to 0.60 can still be accepted. Sorting the value of the object used in this study $>0.6$ a so that if the value of the value of the object $<$ of 0.6 in the calculation of the results of measurement mode (external mode) will be issued from that mode. Based on the results of testing convergent validity which is indicated through the value of outer loadings across indicators in the variable of research shows the value of outer loading of the whole indicator above the 0.6 , so it can be concluded that all indicators of each variable are valid. Measurement outer model other shown through the test of discriminant validity. The Discriminant validity of the outer model is measured by using the sign of the cross to record the value of the signal for any variations at this time. If the value of the cross-reference between the variations of latent and each signal is greater than the correlation with other devices, the variation of latent can cause the signal to predict is better than the other variables. The size of the discriminant validity false only seen from the AVE of each construct, with value exceeds the of 0.50 (Ghozali, 2013).

Table 3. Nilai Average Variance Extracted (AVE)

\begin{tabular}{|l|l|}
\hline \multicolumn{1}{|c|}{ Variabel } & AVE \\
\hline Management Support & 0,627 \\
\hline Support Organization & 0,628 \\
\hline Employee Performance & 0,642 \\
\hline Competence & 0,585 \\
\hline
\end{tabular}

Source : Results of Data Processing with the SmartPLS version 3.2.9 (2020)

From the results of the testing found the value of AVE from the support of the management of 0,627; support the organization of 0,628 ; the performance of employees by 0,642 ; and the competence of 0,585 , which means the construct of the values of AVE exceed of 0.50 . These conditions explain that all of them already meet the criteria.

Test reliability is the reliability test that aims to determine the reliability and trustworthiness of a measuring instrument. A questionnaire is said to be reliable or can be trusted if it depends on whether someone else's answer on a question consistently from time to time. Based on the method of PLS, the reliability of the indicators in this study are clearly visible value on the composite reliabilityserta value on cronbach's alpha for each of the indicators that measure the constructs. 
Construct said to have been reliable if the value of composite reliability and cronbach's alpha exceed of 0.70 (Ghozali and Latan, 2015:41).

Based on the results of the multicollinearity test are obtained each item has a VIF below 4. So can conclusions drawn that there is no expertise further in this study.

After testing the outer model, next is to test the inner model. Testing the inner model is the development of a series of concepts that focused on theory and theory to explore the relationship of different and common.

Table 4. Value $R$ Square $\left(\mathrm{R}^{2}\right)$

\begin{tabular}{|l|r|}
\hline & R Square \\
\hline $\begin{array}{l}\text { Employee } \\
\text { Performance }\end{array}$ & 0,913 \\
\hline Competence & 0,799 \\
\hline
\end{tabular}

Source : Results of Data Processing with the SmartPLS version 3.2.9 (2020)

The relationship between constructs can be described as follows based on the value of $\mathrm{R}$ square in the table above. The R-Square value in the variable performance of employees namely 0,913. These values show that 0,913 or $91.3 \%$ of the variable employee performance can be affected by variables of organizational support, management support and competence are moderate, the rest which amounted to $8.7 \%$ is influenced by variables that exist outside of the researched.The R-Square value in the variable competence of 0,799 . This suggests that the 0,799 or $79,9 \%$ variable competence can be influenced by the variables of organizational support and management support are moderate, the rest, i.e. a $20.1 \%$ influenced by other variables outside the study. In addition, the results of hypothesis testing can be seen through the value of the coefficient between the following variables :

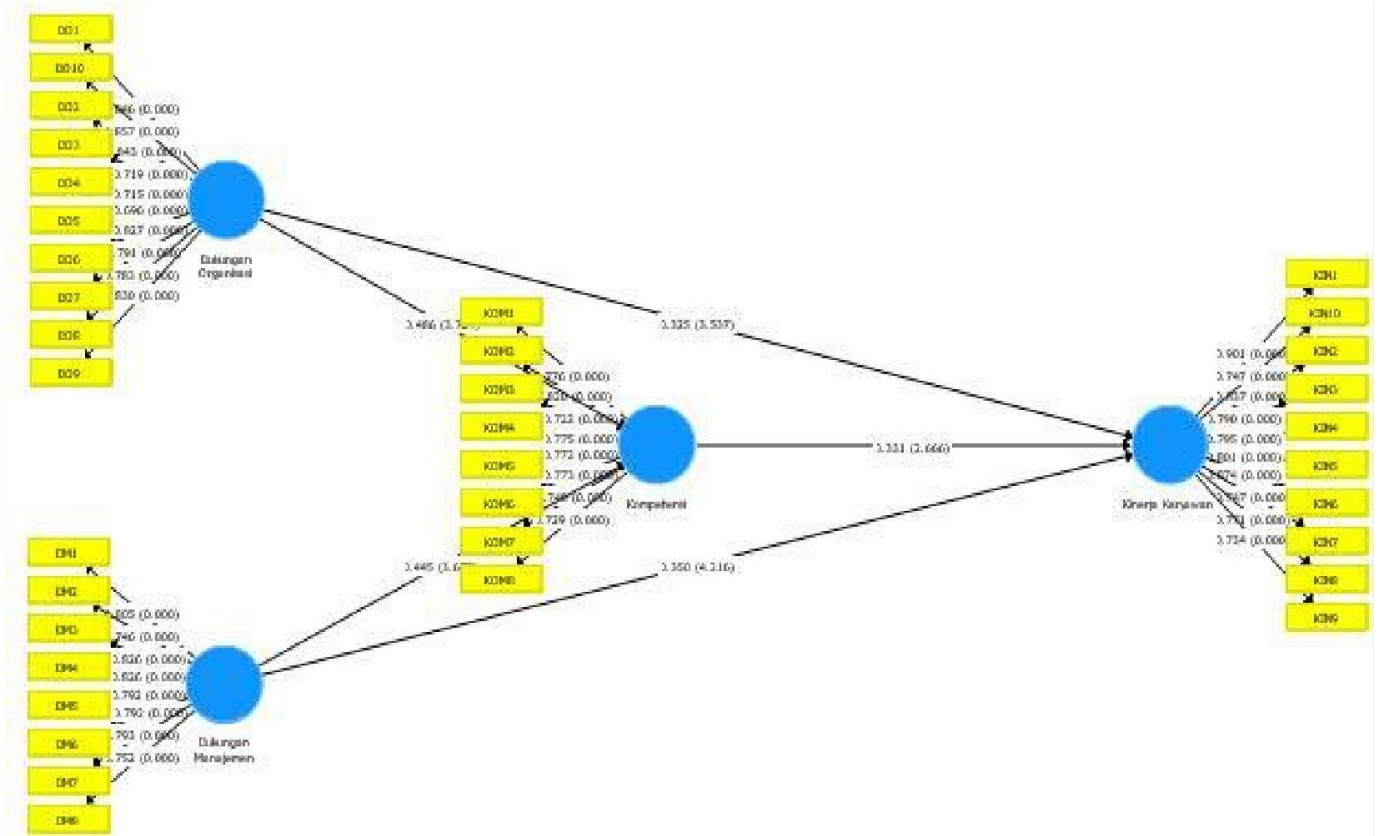

Fig.2. Original Sample (Coeffisient)

Table 5. Value Path Coefficient, $t$-Statistics dan P-Values

\begin{tabular}{|l|c|r|r|}
\hline & $\begin{array}{c}\text { Original } \\
\text { Sample } \\
(\mathbf{O})\end{array}$ & $\begin{array}{c}\text { T Statistics } \\
(|\mathbf{O} / \mathbf{S T D E V}|)\end{array}$ & $\begin{array}{c}\mathbf{P} \\
\text { Values }\end{array}$ \\
\hline Management Support $\rightarrow$ Employee Performance & 0,350 & 4,216 & $\mathbf{0 , 0 0 0}$ \\
\hline Management Support $\rightarrow$ Competence & 0,445 & 3,675 & $\mathbf{0 , 0 0 0}$ \\
\hline
\end{tabular}




\begin{tabular}{|l|r|r|r|}
$\begin{array}{l}\text { Support The Organization } \rightarrow \text { Employee } \\
\text { Performance }\end{array}$ & 0,325 & 3,537 & $\mathbf{0 , 0 0 0}$ \\
\hline Support The Organization $\rightarrow$ Competence & 0,486 & 3,724 & $\mathbf{0 , 0 0 0}$ \\
\hline Competence $\rightarrow$ Employee Performance & 0,331 & 2,666 & $\mathbf{0 , 0 0 8}$ \\
\hline $\begin{array}{l}\text { Management Support } \rightarrow \text { Competence } \rightarrow \\
\text { Employee Performance }\end{array}$ & 0,147 & 2,231 & $\mathbf{0 , 0 2 6}$ \\
\hline $\begin{array}{l}\text { Support The Organization } \rightarrow \text { Competence } \rightarrow \\
\text { Employee Performance }\end{array}$ & 0,161 & 1,991 & $\mathbf{0 , 0 4 7}$ \\
\hline
\end{tabular}

Source : Results of Data Processing with the SmartPLS version 3.2.9 (2020)

\section{The First Hypothesis (H1)}

The results of the first hypothesis on the variable support of the organization against the performance of employees produces value of t-statistics as large as 3,537 >1,981 (t-table), and the value of $\mathrm{P}$-Value $(0,000)$ is lower than 0,05 . Thus $\mathrm{H} 1$ is accepted, so we can conclude that the variable support of the organization affect the performance of employee marketing. Support system is a feature characteristic of, and interfere with energy work, show that support high provided by the organization influence the work force to grow. It depends on the context Moghli (2015) reveal that based on the norm of reciprocity which is done by the enterprise in giving support of high level to the employee then would also be committed against a company by providing performance that is good. Results this hypothesis is consistent with the study done Moghli (2015) and Manyasi et al (2011) that support the organization's positive influence on the improvement of the performance of employees. A similar result is also shown by Mohamed and Ali (2015) and Pham et al (2016) that support the organization significant influential positive towards the performance of employees.

\section{The Second Hypothesis (H2)}

The results from the second hypothesis on the variable support of the management towards the performance of employees produces value of the magnitude 4,216 (t-statistics)greater from1,981 (ttable), as well as the value of P-Value $(0,000)$ was smaller compared to 0,05 . Thus the $\mathrm{H} 2$ is accepted, the conclusion variable support management affect the performance of employee marketing. Support the management of influential positive of significant show that the higher the support of the management Improve the performance of employees. Point of view Ismail et al (2019) stated that the support of management can make employees engaged and motivated to use the knowledge and skills of his to propose ways of improvements in some aspects of the job that needs to be improved. Support management for the evaluation of performance can be referred to as the process schematic to evaluate the performance-based employment and skills of employees (Koshy \& Suguna, 2014). This result is consistent with studies done Baqarah et al (2017) that support the management of the peak influential towards the performance of employees. Identical results are also shown by Karatep \& Kilic (2015) and Prieto-Pastor \& Martin-Perez (2015) find support of the management influence on the performance of employees.

\section{The Third Hypothesis (H3)}

The results of the third hypothesis on the variable support of the organization against the competencies produce value 3,724 (t-statistics)is greater than 1,981 (t-table), as well as the P-Value of 0.000 lower than 0.05 . Thus $\mathrm{H} 3$ is accepted, then the summed variable of organizational support influence on competence.Supports the research carried out on the results of the theory of Ibrahim (2018) find support of the organization affect the performance of employees, where the higher the organizational support, the better the competency possessed by the employees. These results indicate 
that it's getting high support of the organization then it will be getting more impact on the competency of the employee.

\section{The Fourth Hypothesis (H4)}

The results of the fourth hypothesis on the variable management support for competence generate value 3,675 (t-statistics)on top of the 1,981 (t-table), with P-value of 0.000 lower than 0.05 . Thus the $\mathrm{H} 4$ is accepted, it can be concluded variable management support effect on the competence.The results of this theory are consistent with studies that made the Goddess and Badera (2017) demonstrate management support is able to increase competency of the employee. These results show that with the increasing support of management then it will effect on increasing the competence of employees. This is in accordance with the opinion of the Azhar (2007) that the human capacity includes the ability of the individual or of the individual, organization, or plan to carry out a duty or power to achieve its objectives effectively.

\section{The Fifth Hypothesis (H5)}

The results of the fifth hypothesis on the variable of competence on employee performance produces a value of 2,666(t-stat) is greater than 1,981 (t-table), with the value of P-Value 0.008 is below 0.05 . Thus H5 is accepted, and it is concluded that the variable competence affect the performance of employees marketing. The results showed that the efficiency affects the performance of employees. Thus, increasing the capacity of employees and affect employee performance. This is in line with the views of Ryan et al (2009) that employees ' ability to predict performance has the effect that practical.The results of the hypothesis also supports the research done by Putri and Winoto Tj (2016), which reveals the importance of the company's management to improve the ability of employees, especially the technical ability, the ability of the theoretical, conceptual ability and moral capacity in improving the performance of employees. Qiao and Wang (2009) found that the competencies essential to the success of managers in China. Similarly, the research Pereira and Gomez (2012) who found the relationship between individual competencies and performance of employees. Zaim et al, (2013) also found competence significant positive effect on employee performance.

\section{The Hypothesis Of The Sixth (H6)}

The results of hypothesis sixth on the variables of organizational support on employee performance through competencies produce value 1,991 (t-statistics)on top of the 1,981 (t-table), with a P-Value 0,047 below 0.05 . Thus, H6 is accepted, which then concluded variable support the organization influence to employee performance marketing through competence. The results of the hypothesis show that with the support of the organization then it will have an impact on increasing the competence of employees so that it can be influential in increasing the performance of the employee. This is in accordance with the opinion of the Fund and the Goddess (2016) This explains why one of the factors that influence the behavior of employees is the support organization around them. The results of this theory that support the research conducted by the Ilmanier and Jasthuti (2018) showed that organizational support have positive attitude towards the capacity, in particular knowledge management, but do not directly affect the performance of the staff. Demonstrate the ability to be a mediator integrating the support system with the performance of the employees.

\section{Hypothesis Seven (H7)}

The results of hypothesis seventh on the variable management support on employee performance through competencies produce value 2,231 (t-statistics)on top of the 1,981 (t-table), with a P-Value 0,026 below 0.05 . Thus $\mathrm{H} 7$ is accepted, which means the variable management support affect the performance of employees marketing through competence. The results of this hypothesis support the 
research Goddess and Badera (2017) which shows a competency proven to be able to as a mediator that connects between the management support and employee performance. Similar results were also shown by Indrayani et al (2018) found that the competence of employees significant positive effect on employee performance. Meanwhile, Ismai et al (2019) stated that management support can make the employee involved and are encouraged to use the knowledge and skills to propose ways of improvement in some aspects of the work that needs to be fixed. Management support for performance appraisal can be called as the process schematic to assess the performance-based work and skills of workers (Koshy \& Suguna, 2014).

\section{CONCLUSION}

1. Support Organization proven positive effect on Employee Performance Marketing at BPR Nusantara Bona Pasogit (NBP) Group Region of West Java and Banten. It means that with the presence of reciprocity made by the company in providing support to employees in terms of compensation, training, and the provision of clearly defined duties, then the employee will be committed to the company to give the best performance. This shows that the higher the support given by the organization, the less likely to improve performance.

2. Management support proven positive effect on Employee Performance Marketing at BPR Nusantara Bona Pasogit (NBP) Group Region of West Java and Banten. That is with the support of the management then the employees will feel involved and motivated to use their knowledge and skills in completing the work. This indicates that the high-ranking management support the higher level employee performance.

3. Support Organization proven positive effect on the Competence of Employees of Marketing at BPR Nusantara Bona Pasogit (NBP) Group Region of West Java and Banten. It means that the support provided by the organization, such as providing training and compensation it can encourage employees to improve in her ability to achieve the goals of the organization. This shows that it's getting high-support organizations then it will have an impact on increasing the competence of employees in achieving the target expected by the organization.

4. Management support proven positive effect on the Competence of Employees of Marketing at BPR Nusantara Bona Pasogit (NBP) Group Region of West Java and Banten. That is with the support of management such as leadership provide motivation and guidance to employees to provide the best in the organization then employees will be motivated and the spirit to improve their competences so that employee performance can be achieved with maximum results. This shows that the higher the management support it will be increasingly high level of competence of employees in carrying out their work.

5. The competence of the Employees proven Marketing influential positive to Employee Performance Marketing at BPR Nusantara Bona Pasogit (NBP) Group Region of West Java and Banten. That is, employees will do so by using available skills for those in charge of the field work and completed the job carefully so that performance results are better. This refers to the high capacity of employees and increase the efficiency of employees.

6. Support Organization proven positive effect on Employee Performance Marketing through the Competence of Employees of Marketing at BPR Nusantara Bona Pasogit (NBP) Group Region of West Java and Banten. That is with the support of organizations such as the provision of educational programs and the development of a structured to an employee then it will have an impact on increasing the competencies possessed by employees so that they can improve the optimal results. This shows that the higher the level of systematic support in improving the potential of employees, the greater influence on the performance of employees.

7. Management support proven positive effect on Employee Performance Marketing through the Competence of Employees of Marketing at BPR Nusantara Bona Pasogit (NBP) Group Region of 
West Java and Banten. That is with the support of the management such as providing guidance to employees to achieve targets the employee will be motivated to improve the competence examples in these materials so that it will have an effect on the quality of the work the better. This indicates the has a support organization in improving the competence of employees it will have an impact on the performance of the employees.

Efforts to improve the support organization, is expected to the leadership to be able to contribute to the employee in carrying out their duties by providing clear job descriptions, provide facilities and infrastructure that support in completing the duties of employees, the provision of compensation that is fair and transparent in accordance with the contribution of employees in the organization, provide training program can improve the skills of employees, and provide career paths to employees that are fair regardless of status and period of employment.Efforts to improve management support, recommended to improve the ability of conceptual employees, helping to improve the skills of employees through training programs, create working relationships between managers and employees, as well as the relationship between employees. In addition the attitude of the leadership that is transformational so that employees feel comfortable within the organization.

For further research, is expected to be added independent variables such as compensation, leadership, organizational culture and the other which is likely to affect the performance of employees. In addition using variable moderasi in addition to competencies such as employee satisfaction. In addition it is also expected to expand the research sample so that it can provide diversity data and better results.

\section{REFERENSI}

[1] Abou-Moghli, dan Azzam Azmi. (2015). Market Analysis And The Feasibility Of Establishing Small Business. European Scientific Journal, May Edition vol.8, No.9.

[2] Adam, Fikri., dan Kamase, Jeny. (2019). The Effect Competence And Motivation To Satisfaction And Performance. International Journal Of Scientific \& Technology Research, Vol. 8, Issue, 03, hal. 132140.

[3] Afiah, Nunuy Nur dan Indahwati, Rini. (2015). Top-Management Support And User's Competency On The Accounting Information Systems' Quality. IJABER, Vol. 13, No. 6, pp. 4073-4081.

[4] Aryana, P; Tj, HW (2017). Pengaruh Budaya Organisasi, Etika Kerja dan Loyalitas Terhadap Kinerja Karyawan (Study Kasus Pada Karyawan Pendukung Non Akademik Universitas XYZ) Jurnal Ilmiah Manajemen Bisnis, Vol. 17, No. 2, pp. 89-109.

[5] Bangun, Wilson. (2012). Manajemen Sumber Daya Manusia. Jakarta: Erlangga.

[6] Bida, Mohammed Jibrin., Halim, Abdul., dan Majid, Abdul. (2017). Management Support As A Moderator In The $\mathrm{Hr}$ PracticesemployeePerformance Relationship. International Journal of Management Research \& Review, Vol. 7, Issue 1, pp. 13-27.

[7] Boyatzis, Richard, E. (2008). Competencies in The 21 st Century. Journal of Management Development. Vol. 27 No. 1, pp. 5-12.

[8] Cahyadi, Wahyu., Mukhlisin, Murniati.,dan Pramono, S. Eko. (2020). Pengaruh Dukungan Manajemen Puncak Terhadap KualitasSistem Informasi Akuntansi Pada Perusahaan AsuransiSyariah. Jurnal Ilmiah MEA (Manajemen, Ekonomi, dan Akuntansi), Vol. 4 No. 1, pp. 1-10.

[9] Cardy, R. L \& Selvarajan, T. T. (2006). Competencies: Alternative Frameworks for Competitive Advantage. Business Horizons. Vol. 49, pp: 235-245.

[10] Dana, N. M. SashiaAsadanDewi, A. A. S. Kartika. (2016). PengaruhKompensasi Dan DukunganOrganisasiTerhadapKinerjaKaryawan Di Hotel Asana AgungPutra Bali. E-Jurnal ManajemenUnud, Vol. 5, No.9, pp. 5978-6006.

[11] Defrionaldo, dan Rivai, Harif Amali. (2019). Pengaruh Dukungan Organisasi dan Persepsi Keadilan Organisasional Terhadap Kinerja Karyawan Dengan Organizational Citizenship Behavior Sebagai Variabel Mediasi : Studi Pada Karyawan Beacukai Pekanbaru. Jurnal Ilmiah Mahasiswa Ekonomi Manajemen, Vol. 4, No. 3, Agustus: 544-561.

[12] Devita, Maria. (2017). Faktor - Faktor Yang Mempengaruhi Kinerja Karyawan Di Resturant Alpha Hotel Pekanbaru. JOM FISIP, Vol. 4 No. 2, pp. 1-15.

[13] Edy, Sutrisno. (2011). Manajemen Sumber Daya Manusia. Penerbit: Jakarta, Kencana. 
[14] Eisenberger, R., Huntington, R., Hutchison, S. dan Sowa, D. (1986). Perceived Organizational Support.Journal of Applied Psychology, Vol. 71 No. 3, pp. 500-507.

[15] Eisenberger, R., Stinglhamber, F., Vandenberghe, C., Sucharski, I.L., dan Rhoades, L. (2002). Perceived supervisor support: Contributions to perceived organizational support and employee retention. Journal of Applied Psychology, 87, 565-573.

[16] Fristin , Yuntawati., Nimran, Umar., Al Musadieq, M., Utami, H. Nayati. (2019). The Relationship Among Superleader, Perceived Organizational Support and Work Performance Mediated By Work Satisfaction and Employee Engagement. International Journal of Recent Technology and Engineering (IJRTE), Volume 8, Issue-4, pp. 2406-2415.

[17] Fubara., dan Favour, I. (2019). Compensation and Employee Performance of Bank in Port Harcourt, Nigeria. International Journal of Research and Innovation in Social Science, Vol. 3, Issue. 5, hal. 186192.

[18] Ghozali, Imam. (2011). Aplikasi Analisis Multivariate Dengan Program SPSS.Semarang: Badan Penerbit Universitas Diponegoro.

[19] Ghozali, Imam. (2014). Aplikasi analisis Multivariate dengan Program SPSS. Badan Penerbit UNDIP, Semarang

[20] Hair, J.F., Tomas, G.M.H., Ringle, Christian M., dan Marko Sarstedt. (2014). A Primer Partial Least Squares Structural Equation Modeling. Los Angeles: SAGE Publication.Ltd.

[21] Hair,J.F., Tomas, G.M.H., Ringle, Christian M., dan Marko Sarstedt. (2017). A Primer Partial Least Squares Structural Equation Modeling (PLS-SEM) $2^{\text {th }}$ Edition. Los Angeles: SAGE Publication.Ltd.

[22] Ismail, A. Iyanda., Majid, A. H. Abdul., Bida, M. Jibrin., dan Joarder, M. H. Raihan. (2019). Moderating Effect of Management Support on the Relationship Between HR Practices andEmployee Performance in Nigeria. Global Business Review, 1-19.

[23] Kadir, Subhan., Hariadi, Sunarru Samsi., dan Subejo.(2016). Pengaruh Dukungan Organisasi dan Kemampuan Individu TerhadapKinerja Penyuluh Sosial Dan Partisipasi Masyarakat. SOSIO KONSEPSIA, Vol. 6, No. 01, pp. 39-55.

[24] Manani, Enock dan Ngui, Thomas Katua. (2019). Effects Of Employee Competencies On Employee JobPerformance In Humanitarian Organizations; A Case Study OfThe World Food Programme, Kenya.Global Scientific Journals, Vol. 7, Issue 10, pp. 1688-1702.

[25] Martini, I. A. Oka., Rahyuda, I Ketut., Sintaasih, D. Ketut., dan Piartrini, P. Saroyeni. (2018). Influence of Competency on Employee Performance through Organizational Commitment Dimension. IOSR Journal of Business and Management (IOSR-JBM), Volume 20, Issue 2, PP 29-37.

[26] McClelland, D. C. (1973). Testing For Competence Rather Than For Intelligence. American Psychologist, 28, 1-14.

[27] Metria, Ketut dan Riana, I. Gede.(2018). Pengaruh Dukungan Organisasi Terhadap Komitmen Organisasional Dan Kinerja Pegawai. E-Jurnal Ekonomi dan Bisnis Universitas Udayana, vol. 7, no. 9,pp. 2117-2146.

[28] Moghli, AzzamAbou. (2015). The Role of Organizational Support in Improving Employees Performance. International Business Research; Vol. 8, No. 2, pp. 198-203.

[29] Mohamed, S. Ahmed dan Ali, Maimunah. (2015). The Influence of Perceived Organizational Support on Employees' Job Performance. International Journal of Scientific and Research Publications, Volume 5, Issue 4, pp. 1-6.

[30] Murniasih, Erni dan Sudarma, Ketut. (2016). Pengaruh Persepsi Dukungan Organisasi dan Kompetensi Pada Kinerja Karyawan Dimediasi Komitmen Afektif. Management Analysis Journal, 5 (1), pp. $24-35$.

[31] Murtadho, M. Faishal., Nurhayati, Nunung., dan Halimatusadiah, Elly.(2018). Pengaruh Kompetensi Pengguna dan Dukungan Manajemen Puncak Terhadap Kualitas Sistem Informasi Akuntansi (Survei pada Cabng Bank BJB Syariah di Kota dan Kabupaten Bandung). Prosiding Akuntasi, Vol. 4, No. 1, pp. 427-434.

[32] Nawa, Fendra dan Kempa, Sesilya. (2017). Pengaruh Kompensasi Dan Disiplin Kerja TerhadapKinerja Karyawan Pada Pt. Pln (Persero) Wilayah NusaTenggara Timur. AGORA, Vol. 5, No : 3.

[33] Pham, Tuyen Khac., Pham, Cuong Hung., dan Pham Long. (2016). Top Management Support, Organizational Learning, Innovative Behavior, Employee Commitment and Organizational Performance of Manufacturing Companies in Hai Phong. International Journal of Financial Research, Vol. 7, No. 3, pp. 54-64.

[34] Rantesalu, Agustina., Mus, Abdul Rahman., dan Mapparenta., dan Arifin, Zaenal. (2016). The Effect of Competence, Motivation and Organizational Culture on Employee Performance: the Mediating Role of Organizational Commitment. Journal of Research in Business and Management, Vol. 4, Issue. 9, hal. $08-14$ 
[35] Riantoko, Ronny,. Sudibya, I. G. Adnyana,. Dan Sintaasih, D. Ketut. (2017). Pengaruh Dukungan Organisasi Terhadap Motivasi Kerja Dan Kinerjaanggota Polsek Kuta Utara. E-Jurnal Ekonomi dan Bisnis Universitas Udayana, vol. 6, no. 3, pp. 1145-1176.

[36] Ryan, Damian., dan Jones, Calvin. (2009). Understanding Digital Marketing: Marketing Strategies for Engaging The Digital Generation. United States: Kogan Page Limited.

[37] Sevilla, Consuelo G. (2007). Research Methods. Rex Printing Company. QuezonCity.

[38] Siddiqi, Tahmeem., dan Tangem, Sadia. (2018). Impact of Work Environment, Compensation and Motivation on The Performance of Employees in The Insurance Companies Of Bangladesh. South East Asia Journal of Contemporary Business, Economics and Law, Vol. 15, Issue. 5, pp. 153-162.

[39] Siregar, Syofian. (2013). Metode Penelitian Kuantitatif. Jakarta: PT Fajar Interpratama Mandiri.

[40] Sugiyono. (2016). Metode Penelitian Kuantitatif, Kualitatif dan R\&D. Bandung: PT Alfabet.

[41] T. K. Putri, Tj, HW (2016). Pengaruh Pendidikan dan Pelatihan Kerja Serta Lingkungan Kerja Terhadap Kinerja Karyawan PT Inplasco Prima Surya Jurnal Ilmiah Manajemen Bisnis, Vol. 16, No. 1, pp. 2544.

[42] Yuniasih, Yuyun dan Herdiana, Heri. (2017). Pengaruh Kompetensi Individu, Komitmen Organisasi dan Iklim Organisasi PadaKinerja Dosen. Jurnal Ekonomi Manajemen, Vo. 3, No. 1, pp. 28-34.

[43] Zaim, Halil., Yasar, Mehmet Fatih., Unal, Omer Faruk. (2015). Analyzing The Effects Of Individual Competencies OnPerformance: A Field Study In Services Industries In Turkey. Journal of Global Strategic Management. 